\title{
Clotting Phenomena at the Blood-Polymer Interface and Development of Blood Compatible Polymeric Surfaces
}

Adriaan Bantjes

\begin{abstract}
In the past two decades many attempts have been made to relate surface and interfacial parameters with the blood compatibility of polymeric surfaces. It is however doubtful if by a single parameter the behaviour of blood on a surface can be predicted. Two major aspects of blood compatibility - the prevention of platelet adhesion and the deactivation of the intrinsic coagulation system are determined by the measure and nature of competitive blood protein adsorption on the foreign surface. The adhesion of blood platelets is promoted by adsorbed fibrinogen and gamma globulin, while adsorbed albumin inhibits platelet adhesion. Heparinised surfaces do not adsorb fibrin and consequently no adhesion of platelets takes place. Other surfaces with low platelet adhesion are the hydrogels, certain block copolyetherurethanes, polyelectrolyte complexes and biolised proteins. Heparinised surfaces of the cationically bonded type inhibit the intrinsic coagulation as well, however this may be due to unstable coatings and heparin leakage.

In the authors laboratory a synthetic heparinoid was prepared with the structure

$$
-\left[\mathrm{CH}_{2}-\mathrm{C}\left(\mathrm{CH}_{3}\right) \mathrm{NHSO}_{3} \mathrm{Na}-\mathrm{C}(\mathrm{H}) \mathrm{COONa}-\mathrm{CH}_{2}-\right]_{\overline{\mathrm{x}}}
$$

with $\ddot{M}_{w}=(7.5+1.0) \times 10^{5}$ and an in vivo anticoagulant activity of $50 \%$ of heparin. Its coatings on PVC, using tridodecylmethyl-ammonium chloride as a coupling agent, are stable in plasma and salt solutions and provide surfaces which show negligible platelet adhesion and a strong inhibition of the intrinsic coagulation on contact with blood. Similar results were found with polydimethylsiloxane surfaces coated with this heparinoid.
\end{abstract}

\section{INTRODUCTION}

The clinical use of blood contacting devices and prostheses is of major importance today in cardiovascular surgery and other fields of medicine. Heart valve - and blood vessel prostheses, balloon pumps, and catheters are being implanted in daily surgical practice to restore or diagnose cardiovascular function. Artificial organs are routinely employed in blood dialysis (artificial kidney), in blood detoxification by adsorptive haemoperfusion and in oxygenation (membrane oxygenators and heart-lung devices). Considerable effort and capital is invested in Europe and the USA in the development and experimental evaluation of an implantable artificial heart system. These devices are generally constructed from polymeric materials and when in use a blood-polymer contact is present. This contact will cause a reaction in the recirculating blood, which, depending on the materials choice, the design parameters, the flow or the addition of anticoagulants may lead to protein deposition, adhesion and destruction of red blood cells (haemolysis), platelet (thrombocyte) adhesion and aggregation and blood coagulation leading to the formation of a haemostatic plug (thrombus) (Fig. 1). The occurrence of thromboembolism in cardiovascular surge ry continues to be a problem, notwithstanding routine treatment with anticoagulants. For these reasons the search for blood compatible nonthrombogenic materials has been an important research objective over the last two decades. ${ }^{1-3}$ For a perception of the routes along which

Biomaterials Section,

Department of Chemical Technology,

Twente University of Technology,

Enschede,

The Netherlands new blood compatible materials may be developed it is necessary to explain some of the mechanisms of blood coagulation on interaction with a foreign surface.

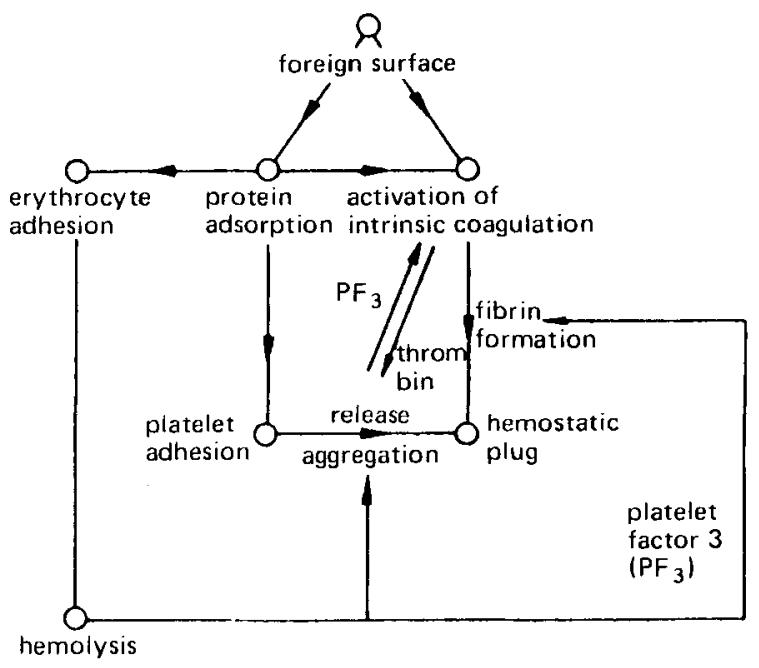

lï.1 Blood-foreign surface contact phenomena.

\subsection{Protein adsorption}

The very first event on blood-polymer surface contact is a rapid adsorption of plasma proteins from the blood on to the material surface. Upon adsorption of plasma proteins the material surface will be altered and the subsequent events will be determined by the modified surface. The relation between the character of the polymeric surface and the rate of protein adsorption and the composition and thickness of 
the adsorbed protein layer is today largely unknown, notwithstanding the numerous research reports and publications in this area. 4-6 Protein adsorption generally follows a Langmuir adsorption type ${ }^{7,8}$ and hydrophobic surfaces in teract more strongly with proteins ${ }^{9}$ and adsorb more protein than hydrophilic surfaces. ${ }^{4}$ Generally hydrophobic surfaces adsorb proteins irreversibly. ${ }^{10}$ There are strong in dications that preferential adsorption of one type of blood protein over another may play an important role in the sequential events - platelet adhesion and coagulation. Many polymers adsorb fibrinogen rapidly, ${ }^{11}$ which in its turn can promote the adhesion of blood platelets. ${ }^{12-14}$ For certain block copolyetherurethanes it was reported that a high and specific albumin adsorption determines its high blood compatibility. ${ }^{15}$

Heparin coated surfaces do not adsorb fibrinogen and platelets do not adhere on these surfaces. ${ }^{16-18}$ Although a number of authors report on competitive adsorption studies with radiolabelled proteins, ${ }^{19,20}$ more work is necessary to obtain necessary insight in the first phase of the blood coagulation. In the authors laboratory a study in dicated that one should be extremely careful in the selection of the radiolabelled proteins. $^{21}$ Several procedures for labelling proteins resulted in unstable labels, but even stable ${ }^{99 \mathrm{~m}} \mathrm{Tc}$ and ${ }^{125}$ I labelled serum albumin showed preferential adsorption over unlabelled albumin. For better understanding of blood coagulation the work on competitive adsorption of blood proteins should continue but with biologically produced radiolabelled starting materials where the danger of preferential adsorption is minimised.

Fig. 2 gives a schematic sequence of events following the protein adsorption, which are described below in more detail.

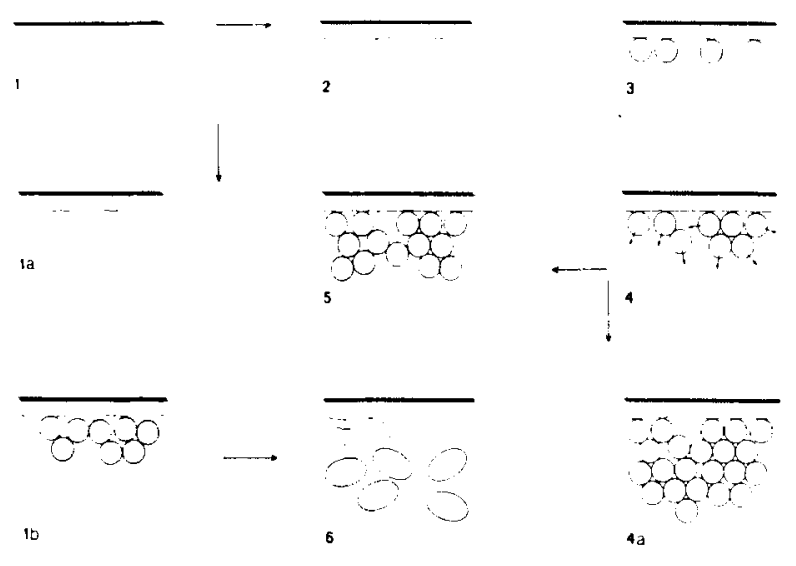

Fig.2 Interaction of a forcign material with blood.

1. Exposure of blood to a foreign material

2. Adsorption of proteins from the blood onto the foreign material.

3. Adhesion of platelets to the adsorbed protein layer.

4. Release of ADP and other platelet constitutents. Formation of a platelet aggregate.

5. The coagulation process is started on the surface of the aggregating platelets. Formation of an insoluble fibrin network.

6. Individual platele ts lose their in tegrity and fuse with each other. librin strands with entrapped cells from the blood form a red thrombus.

$4 a$ Formation of a white thrombus by aggregating platelets.

la The coagulation process is started by activation of factor XII on the foreign surface.

$I b$ Thrombin is formed during the coagulation process, resulting in platelet aggregation.

\subsection{Platelet adhesion and aggregation 22,23}

The adhesion of thrombocytes on a polymer surface is presumably caused by the formation of an enzyme-substrate complex between the enzyme glycosyl transferase on the thrombocyte's surface and heterosaccharides of the adsorbed glycoproteins fibrinogen and gamma globulin. ${ }^{24,25}$ Sugar nucleotides can then be transferred from the platelet to the protein. This is not possible with albumin as it is a pure protein and saccharide chains are not present here. This adhesion mechanism is similar to that suggested for the interaction of platelets with collagen in case of damage to the wall of a blood-vessel. ${ }^{26}$ After adhesion the platelets show tentacle like protrusions, the pseudopods; they then contract and undergo the release reaction, whereby adenosine diphosphate (ADP), serotonine and other substances are freed. ADP causes more platelets to stick to those already adhering. Thus platelet aggregation takes place as an autocatalytic process. In a still later phase the platelet aggregates undergo 'viscous metamorphosis', fusion in to a homogeneous white thrombus. When at the thrombocyte surface enzymatic coagulation factors are activated the result will be a red thrombus, built up of fibrin fibres, platelets, red cells and other blood components. When anticoagulants are present fibrin is not formed and only a white thrombus forms as has been observed in arterial-venous shunts under conditions of heparinisation. 27

\subsection{Intrinsic coagulation}

Intrinsic coagulation is a complicated process of a number of reactions occurring mainly between soluble proteins in blood or plasma. The final step is the conversion of soluble fibrinogen into insoluble fibrin fibres. The proteins are called coagulation factors. Table 1 summarizes the accepted Roman numerals and synonyms for these factors. Factors converted to their enzymatically active form are indicated with a suffix below the Roman numeral. The coagulation schema given by Fig. 3 is based on recent data ${ }^{28}$ and shows the sequential activation of the factors in a "cascade mechanism'. The coagulation is set in motion by activation of factor XII, the Hageman factor, through adsorption on a foreign surface. The activated factor XII (XIIa) activates factor XI on the surface proteolytically. Calcium ions play an important part in the activation of a number of factors. The coagulation process and the adhesion and aggregation of platele ts proceed independently although in the later phases of platelet aggregation interaction with the blood coagulation may occur.

The influence of flow conditions on platelet adhesion and intrinsic coagulation are not dealt with here, but are described else where. ${ }^{28 a}$

\subsection{Anticoagulation}

To prevent coagulation direct or indirect anticoagulants are used. The latter type prevents the biosynthesis of some coagulation factors. An example is 4-hydroxy coumarin. A direct anticoagulant is he parin 29,30 (see Fig. 4), a muco polysaccharide carrying sulphate, sulphamate and carboxylate groups. Depending on its natural source its $\bar{M}_{\mathrm{w}}$ may vary from $8-20,000$. Its activity is based on the catalytic activation by heparin of antithrombin III, the heparin cofactor, which is present in the blood. Activated AT III forms complexes with thrombin 31,32 and also with the activated factors VIIa, ${ }^{33} \mathrm{IXa}^{34}{ }^{34} \mathrm{Xa}^{35}$ and XIa,${ }^{36}$ thus in hibiting coagulation and fibrin formation. Heparin does not occur freely in the blood, but it is present in the blood-vessel walls. ${ }^{37-39}$ Its half-life in the body is around 1.5 hours. ${ }^{40}$ The molecular basis for the anticoagulant activity is not very well understood.

Other naturally occurring sulphated polysaccharides are considerably less or not at all active. ${ }^{41.43}$ However the presence 
and level of sulphamate groups $44-45$ is of essence for its activity, which also depends on the molecular ${ }^{46}$ weight.

Table 1. Coagulation Factors

\begin{tabular}{|c|c|c|}
\hline number & name & synonyms \\
\hline 1 & fibrinogen & \\
\hline II & prothrombin & \\
\hline 111 & thromboplastin & \\
\hline IV & calcium ion & \\
\hline V & proaccelerin & labile factor \\
\hline VI & (not used) & \\
\hline VII & proconvertin & autoprothrombin I \\
\hline VIII & $\begin{array}{l}\text { antihemophilic } \\
\text { factor } A\end{array}$ & $\begin{array}{l}\text { antihemophilic globulin, } \\
\text { plasma thromboplastin } \\
\text { factor A }\end{array}$ \\
\hline IX & Christmas factor & $\begin{array}{l}\text { plasma thromboplastin } \\
\text { component, antihemophilic } \\
\text { factor B, autoprothrombin II, } \\
\text { plasma thromboplastin } \\
\text { factor B }\end{array}$ \\
\hline$x$ & Stuart-Prower factor & autoprothrombin C \\
\hline$x \mid$ & $\begin{array}{l}\text { plasma thromboplastin } \\
\text { antecedent }\end{array}$ & $\begin{array}{l}\text { plasma thromboplastin } \\
\text { factor } C \text {, antihemophilic } \\
\text { factor } C\end{array}$ \\
\hline$x \mid 1$ & Hageman factor & contact factor \\
\hline$x \mid 11$ & $\begin{array}{l}\text { fibrin stabilising } \\
\text { factor }\end{array}$ & Laki-Lorand factor \\
\hline
\end{tabular}

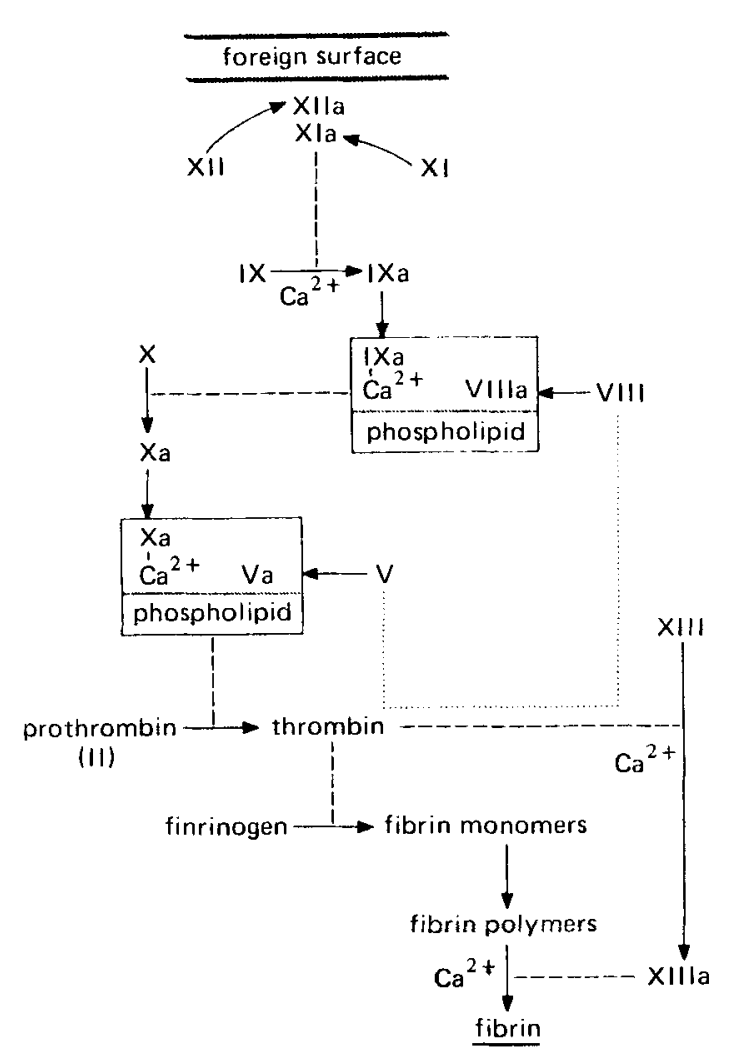

lig. 3 The "cascade' mechanism of in trinsic coagulation.

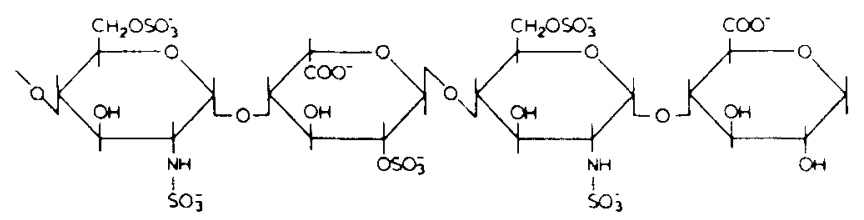

Fig.4 The structure of heparin.

\section{BLOOD COMPATIBLE MATERIALS}

For the correlation with blood-surface interaction phenomena a number of parameters were suggested - surface and interfacial parameters, surface charge and $\zeta$ potential, conductivity and domain structure.

\subsection{Surface and interfacial parameters 47}

A first attempt to relate surface properties with bood compatibility dates from 1930.48 It was stated that clotting time was inversely proportional to the wettability of a surface. It is however generally incorrect to state that a hydrophobic surface is less thrombogenic than a hydrophilic one. Much later surface free energy or surface tension, defined as $\gamma=F-F^{\prime} / A$

( $F=$ free energy of the bulk, $F^{\prime}=$ free energy of

the surface, $A=$ surface area), was considered as a criterion for blood compatibility. ${ }^{49,50}$ It is more logical to consider the interface of the polymer with blood, and the interfacial free energy defined as $\gamma_{S L}=\gamma_{S}-\gamma_{S \mid L]}+\gamma_{L}-\gamma_{L[S \mid}$ has been considered as a parameter. ${ }^{51}$

( $\gamma_{S}$ and $\gamma_{L}$ are the surface tensions of the solid and liquid respectively and $\gamma_{S|L|}$ and $\gamma_{L|S|}$ express the effect of one phase upon another).

When a drop of liquid is placed on a surface the equilibrium spreading of the liquid is given by the Young-Dupre relation: $\gamma_{\mathrm{SV}}=\gamma_{\mathrm{SL}}+\gamma_{\mathrm{LV}} \cos \theta$

$\left(\theta=\right.$ contact angle, the interfacial tensions are given by $\gamma_{\mathrm{SV}}$ (solid vapour), $\gamma_{\mathrm{SL}}$ (solid-liquid) and $\gamma_{\mathrm{LV}}$ (liquid vapour).

From contact angle measuremens the surface free energies of polymers were calculated. ${ }^{49}$ These data were used later to generate data for the interfacial tensions, ${ }^{52,53}$ but some questionable assumptions make these data at best rough estimations. This notwithstanding, materials with a minimal interfacial energy like hydrogels do possess a low thromboadherence. Zisman correlated the contact angle $\theta$ with the $\gamma_{L}$ for the interface of the components of a homologous series of liquids on polymers. ${ }^{54}$ The empirical relation $\cos \theta=a-b \gamma_{L}$ was found.

The critical surface tension $\gamma_{C^{\prime}}$ defined as $(a-1) / b$ or the value of $\gamma_{L}$ for which $\theta=0$ was also used as a parameter, ${ }^{55}$ though an inadequate one because of the dependence of $\gamma_{C}$ on the series of liquids used. ${ }^{56}$ It must be doubted that by a single surface or interfacial parameter the behaviour of blood on a surface can be predicted.

\subsection{Surface charge 57.58}

The blood-vessel wall has a negative $\zeta$ potential of -8 to -13 $\mathrm{mV} .{ }^{59}$ This surface charge may act by repulsion of negatively charged blood componen ts such as cells and proteins. Electrets with a negative surface charge generally show better blood compatibility than the non polarised polymeric surface. ${ }^{60}$ Not all negatively charged polymer surfaces are antithrombogenic; poly(styrene sulphonate) causes as much coagulation as polystyrene itself. ${ }^{61}$ Positively charged or polarised surfaces are however generally thrombogenic. ${ }^{62}$ In teresting are the complexes of polycations with an excess of polyanions, which show antithrombogenic properties. ${ }^{63}$

\section{MATERIALS USED FOR BLOOD-CONTACT APPLICATIONS}

Common commercial polymers such as silicone rubbers, poly- 
olefins, polyvinylchloride, polytetrafluorethylene, cellulosics, polyesters and polyamides are thrombogenic and application of anticoagulants is indicated. Velours, knits and porous structures are use $d$ for prolonged periods as they are designe $\mathrm{d}^{64}$ to trap clots and promote ingrowth ${ }^{65}$ of fibroblastic and endothelial cells, thus producing a living surface which simulates the inner wall of the blood-vessels. Certain polyurethanes, in particular the block copolyetherurethane urea type (PEUU) ${ }^{66,67}$ are built up of polypropyleneoxide or poly tetrame thyleneoxide (M.W. 1025) segments with methylene (4-bis phenyl isocyanate) and aliphatic diamines such as ethylene diamine as chain extenders. Another type, Avcothane, is a block copoly (dialkyl siloxane) urethane. ${ }^{68}$ These polymers show remarkably good blood compatibility, due to their high albumin and low fibrinogen adsorption. ${ }^{69}$ The underlying reasons for this specific adsorption behaviour is poorly understood; the platelet adhesion is favourably affected by the types showing a minimal phase separation. ${ }^{70}$ Their excellent flex properties and good solubility make these materials very suitable for the construction of artificial hearts. ${ }^{71}$

Hydrogels are polymers which exhibit the ability to swell in water and retain more than $20 \%$ water within its structure. ${ }^{72}$ They provide a very low interfacial free energy system with water or blood. The best known types are poly(hydroxyethyl) methacrylate, polyacrylamide and copolymers containing poly(N-vinyl pyrrolidone-2). These types of polymer belong to the most non thromboardherent systems, but recent results with hydrogel grafted arterial-venous shunts in dicate an increasing platelet destruction ${ }^{73}$ level with increasing water content in in vivo tests.

Polyelectrolyte complexes are hydrogel-like combinations of polycations and polyanions. Complexes of poly(vinyl benzyltrimethyl ammonium) chloride or poly(diallyldimethyl ammonium) chloride with a slight excess of sodium poly (styrene sulphonate), also known as Ioplexes, ${ }^{73 \mathrm{a}}$ show good an tithrombogenicity. A general problem with all hydrogel polymers is their lack of mechanical strength.

Albumin coated surfaces do not at tract thrombocy tes and have found succesfull clinical application. ${ }^{74}$ Preliminary in vitro experiments carried out in our laboratory indicate that the activation of the intrinsic coagulation is not purely dependent on the type of preadsorbed protein but also on the nature of the material.

Biolized surfaces 75 are generally composite structures of which a rough surfaced elastomeric material is treated with a solution of albumin or gelatin. ${ }^{76}$ Then a treatment with formal dehy de or glutaraldehy de is given to effect crosslinking.

Heparinized surfaces are generally obtained by ionically linking of heparin to a polymer surface by means of quaternary ammonium groups. These groups may be provided by low molecular weight detergents ${ }^{77-79}$ such as tridodecyl methyl ammonium chloride (TDMAC) or benzalkonium chloride ${ }^{80}$ as coupling agents or they may be introduced chemically in to the polymer or on the surface. An example is the grafting of styrene by radiation to various polymers and subsequent chloromethylation and amination. ${ }^{81}$

Heparinisation with TDMAC as a coupling agent may be carried out in two ways:

(a) by a two step method where first TDMAC is brought into contact with the polymer in the presence of a swelling agent. After drying a second treatment follows with an aque ous solution of heparin to provide the final coating.

(b) a one step method in which a TDMA-heparin complex is made and direct coating takes place from a complex solution in an organic solvent. ${ }^{82,83}$

The final coating can be stabilised by crosslinking with glut araldehyde solution. ${ }^{84,85}$ Other methods for obtaining heparinised surfaces are:

(a) mixing of heparin through the polymer before processing. 86,87 These surfaces show leakage of heparin after blood contact.

(b) covalent bonding of heparin through radiation grafting 88 or reactive groups (isocyanate, ${ }^{89}$ cyanuric chloride). ${ }^{90}$ Unfortunately the covalently attached heparin is much less active in preventing coagulation than the ionic complexes.

(c) by using polymeric coupling agents with cationic linking groups. ${ }^{18}$

The activity of heparinised surfaces rests on their capacity to bind and activate antithrombin III on the surface. 32 Thrombin is then neutralised by the bound antithrombin III and actually broken down so that heparin bound antithrombin III becomes again available for renewed thrombin deactivation. This mechanism also applies to the deactivation of factors $\mathrm{IXa}, \mathrm{Xa}$ and XIa. ${ }^{35}$ Fibrinogen adsorption from blood does not take place on these surfaces and platelets do not adhere. ${ }^{91,16,17}$ Some doubt exists concerning the stability of the ionically bonded heparine and several authors claim that leaching of heparin from the surface could well be the reason for the anticoagulant activity. ${ }^{81,90,92}$

\subsection{Heparinoid systems ${ }^{93}$}

In our labozatory a number of heparinoids have been synthesised by reaction of unsaturated polymers like poly(cis-1, 4 isoprene $)^{94}$ with the specific reagent $\mathrm{N}$-chlorosulphonyl isocyanate, ${ }^{95,96}$ which adds to $\sim 70 \%$ of the double bonds:<smiles>CCCC(C)=CC[13CH2]C</smiles><smiles>CCC1C(=O)N(S(=O)(=O)Cl)C1(C)CC</smiles>

I

The polymeric beta lactam sulphonyl chloride is then hydrolyzed with a $2 \mathrm{~N}$ sodium hydroxide solution to polyelectrolyte $P$<smiles>CC(O)(I)CC(C)(CC(C)([N+](=O)[O-])[N+](=O)[O-])C(=O)O[Na]</smiles>

$\mathbf{P}$ 
For polyelectrolyte $\mathrm{P}$ the starting material was pharmaceutical grade poly(cis-1, 4 isoprene) Shell Cariflex 307$), \bar{M}_{\mathrm{W}}: 2.4 \mathrm{x}$ $10^{6}$ ). Polyelectrolyte $P$ contains the same sulphamate and carboxylate groups we find in heparin, though no sulphate groups are present. The product is a watersoluble, white crystalline material with a $\bar{M}_{\mathrm{W}}$ of $(7.5 \times 1.0) \times 10^{5}$. It is a non toxic and nonpyrogenic ${ }^{97}$ direct anticoagulant with an in vivo activity of $50 \%$ that of heparin. 98

In many ways its activity is similar to that of heparin, ${ }^{99}$ with the exception of possessing a much stronger antipolymerase activity in the polymerisation of the fibrin monomer. Its biodegradation in vivo (rabbit tests) is similar but slightly slower than heparin itself. Contrary to heparin it will undergo gamma sterilisation without loss of activity. The presence of both sulphamate as well as carboxylate groups is essential for the anticoagulant activity. Acid cleavage of the N-S bond to an extent of $50 \%$ as well as substitution of the carboxylate group by carbonamide resulted in loss of activity. ${ }^{100}$ A similar product synthesised from poly (trans 1, 4-isoprene), Polysar $1821, \bar{M}_{\mathrm{W}}: 4.3 \times 10^{6}$, gave an almost identical product, though configurationally different, with an anticoagulant activity of only half that of polyelectrolyte $P$.

\subsection{Coating of surfaces with polyelectroly te P-TDMA complexes}

In analogy with the TDMA-he parin coatings, one and two step coatings were applied to PVC surfaces, substituting the polyelectrolyte $P$ for heparin. The PVC used was of a very pure grade (Breon $\$ 110 / 10, \bar{M}_{\mathrm{W}}: 56000, \bar{M}_{\mathrm{n}}: 28000$ ). Solvent swelling of PVC is necessary for the uptake of TDMAC. An adsorption isotherm at $20^{\circ}$ of TDMAC on PVC in toluene was determined (Fig. 5). From these data and from the determination of the fraction of the TDMAC on the polymer surface, which is capable of ${ }^{36} \mathrm{Cl}^{-}$exchange, it becomes clear that most of the TDMAC is dissolved in the polymer and only a fraction is available for ion exchange (Table 2.)

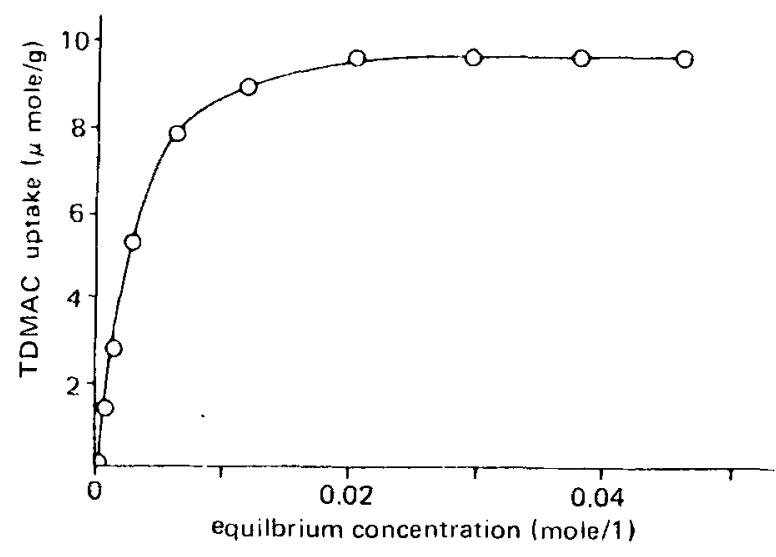

I:ig. 5 Sorption isotherm of TDMAC by PVC from toluene solution at $20^{\circ} \mathrm{C}$.

Table 2. Chloride exchange of TDMAC adsorbates with ${ }^{36} \mathrm{Cl}^{-}$

\begin{tabular}{cc}
\hline $\begin{array}{l}\text { Total TDMAC present } \\
(\mu \text { mole/gPVC) }\end{array}$ & $\begin{array}{l}\text { Exchangeable } \mathrm{Cr} \\
(\mu \mathrm{mole} / \mathrm{g} P \mathrm{PV})\end{array}$ \\
\hline 4.247 & 0.0515 \\
6.056 & 0.2167 \\
7.125 & 0.3051 \\
\hline
\end{tabular}

Little is known about the theory of polyelectrolyte adsorption on a countercharged surface. One treatment exists however, which states that the number of adsorbed units reaches a saturation value when the polyelectrolyte concentration increases. ${ }^{101}$ The number of dangling chain segments 102 (loops and tails) greatly increases near this saturation value of the number of trains. So the ionic attachment of the adsorbed layer decreases with increasing polyelectrolyte concentration. For overall adsorption and desorption studies the polyelectrolyte $\mathrm{P}$ was labelled with ${ }^{125} \mathrm{I}$, using a modification of the Greenwood procedure. ${ }^{100}$ As in the complex formation for each ionic bond formed a chloride ion is freed, the number of adsorbed polymer segments could be determined from the exchange of ${ }^{36} \mathrm{Cl}^{-}$. Table 3 gives the number of adsorbed polyelectrolyte seg. ments per molecule. Desorption experiments with ${ }^{125} I$ labelled polyelectrolyte in saline solution $(0.15 \mathrm{M})$ and bovine plasma showed irreversible adsorption of the heparinoid. The adsorbed layer can be described as a quasi solution where all molecules are linked to the surface through a number of segments at all time. ${ }^{104}$

Table 3. Determination of the number of adsorbed segments per polyelectrolyte molecule

\begin{tabular}{lccc}
\hline $\begin{array}{l}\text { TDMAC/PVC } \\
\text { ion-exchange } \\
\text { capacity }\end{array}$ & $\begin{array}{l}\text { adsorbed } \\
\text { poly- } \\
\text { electrolyte } \\
\mu e q / g\end{array}$ & $\begin{array}{l}\text { released } \\
\text { chloride } \\
\mu e q / g\end{array}$ & $\begin{array}{l}\text { number of } \\
\text { adsorbed seg- } \\
\text { ments per } \\
\text { molecule }\end{array}$ \\
\hline 0.0515 & $3.9^{\mathrm{b}}$ & 0.034 & 34.4 \\
& 14.1 & 0.035 & 9.8 \\
& 24.0 & 0.036 & 5.9 \\
& 46.3 & 0.039 & 3.3 \\
0.2167 & 62.7 & 0.039 & 2.5 \\
& 4.9 & 0.096 & 77.4 \\
& 14.4 & 0.096 & 26.3 \\
& 28.1 & 0.095 & 13.4 \\
& 36.4 & 0.096 & 10.4 \\
0.3051 & 68.2 & 0.094 & 5.4 \\
& $3.5^{c}$ & 0.156 & 176.0 \\
& 12.1 & 0.155 & 50.6 \\
& 28.6 & 0.153 & 21.1 \\
& 43.2 & 0.153 & 14.0 \\
& $78.4^{c}$ & 0.153 & 7.7 \\
\hline a From adsorption experiments with labeled polyelectrolyte \\
b Samples of this composition used for desorption experiments
\end{tabular}

\subsection{Blood contact properties of heparinoid coatings}

Coagulation experiments were carried out by recalcification of plasma and whole blood in coated tubes at $37^{\circ}$. Results are given in Table 4 and 5 , which indicate the nonthrombogenicity of the coatings. Threshold values of between 8 and $14 \mathrm{mg} / \mathrm{m}^{2}$ of the heparinoid seem to be required for nonthrombogenic behaviour. Platelet adhesion was measured in an ex vivo cell system based on the experimental approach of Mason et al. 105-107 A physiological salt solution is displaced from the cells by native blood in the absence of an air-blood interface. The blood is slowly pumped through a series of parallel flow cells of which one contains a reference material and the others the various test polymers in sheet form. An exploded view of the cell is given in Fig. 6. 


\begin{tabular}{lcc}
\hline & $\begin{array}{l}\text { clotting time } \\
\text { after } \\
\text { recalcification } \\
(\mathrm{min})\end{array}$ & $\begin{array}{l}\text { clotting time after } \\
\text { transfer from test } \\
\text { material to glass } \\
(\mathrm{min})\end{array}$ \\
\hline Material & 3 & - \\
glass & 12 & - \\
PVC (uncoated) & $15-20$ & - \\
PVC/TDMA-P. & $>60$ & 3 \\
$\begin{array}{l}\text { PVC/TDMA-P, } \\
\text { methyl acetate }\end{array}$ & & \\
washed & $>60$ & $>30$ \\
PVC/TDMA-heparin & & \\
\hline
\end{tabular}

Table 5. Experiments with two-step coatings; human plasma

\begin{tabular}{|c|c|c|c|}
\hline $\begin{array}{l}\text { TDMAC } \\
e q / m^{2}\end{array}$ & $\begin{array}{l}P \text { bound } \\
m g / m^{2}\end{array}$ & $\begin{array}{l}\text { recalcification } \\
\text { time (min) }\end{array}$ & $\begin{array}{l}\text { clotting time after } \\
\text { transfer to glass } \\
\text { (min) }\end{array}$ \\
\hline 0 & 0 & 12 & - \\
\hline \multirow{3}{*}{0.05} & 0.6 & $12-15$ & - \\
\hline & 7.4 & $12-15$ & - \\
\hline & 14.8 & $>60$ & 4 \\
\hline \multirow[t]{3}{*}{0.30} & 2.1 & $12-16$ & - \\
\hline & 15.4 & $>60$ & 4 \\
\hline & 23.7 & $>60$ & 4 \\
\hline
\end{tabular}

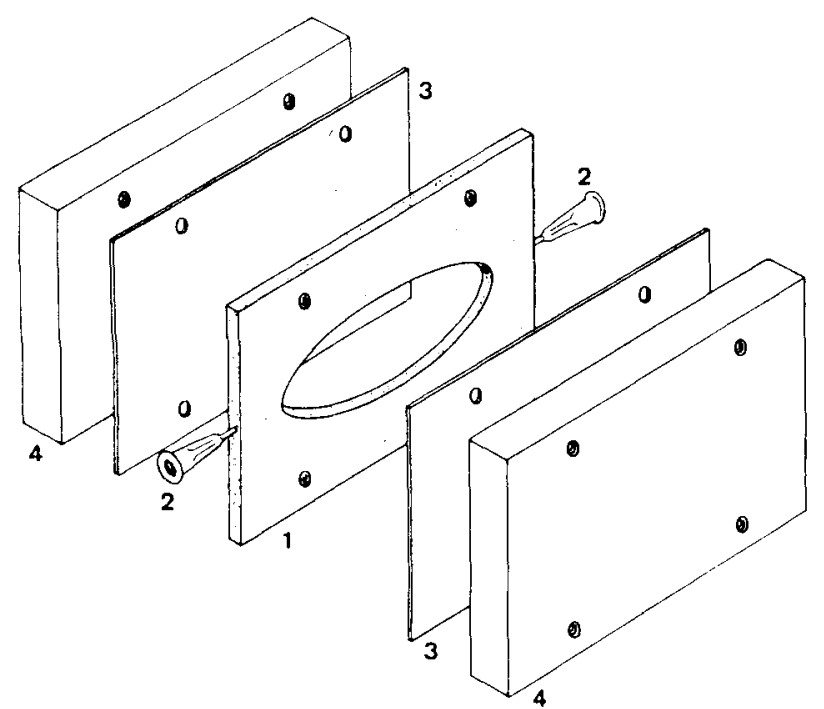

Fig. 6 Exploded view of a flow cell, based on the experimental approach of Mason.

1. Silastic rubber gasket, $3 \mathrm{~mm}$ thick, with elliptical cut out. The ax is of the ellips are 63 and $24 \mathrm{~mm}$.

2. Inlet and outlet of the ccll, consisting of cut off needles (Luer P), $1.20 \mathrm{~mm}$ thick.

3. Sheets of the material to be tested.

4. Lucite support blocks. The holes in one support block are threaded in ternally; the other block has plain holes.

The cell is assembled with the aid of four bolts.

Platelet adhesion and fibrin deposition were studied ${ }^{108}$ by scanning electron microscopy after giutaraldehyde fixation, rinsing and vacuum coating with a conducting layer of carbon and gold on the surfaces. Table 6 gives the results of platelet adhesion and PTT times. The heparinoid coated surfaces showed a very low platelet adhesion. In the very few platelets visible on the surface no pseudopods could be observed.
Table 6. Adhesion of Platelets and Activation of Intrinsic Coagulation

\begin{tabular}{lcc}
\hline Material & $\begin{array}{l}\text { Adhering Platelets on } \\
0.01 \mathrm{~mm}^{2}\end{array}$ & $\begin{array}{c}\text { PTT value in } \% \\
(P S=100 \%)\end{array}$ \\
\hline glass & $33-59$ & 65 \\
polystyrene & $13-21$ & 100 \\
PVC & $13-18$ & 100 \\
PVC/TDMA-P & $1.5-3.0$ & $103-113$ \\
\hline
\end{tabular}

\subsection{The nonthrombogenicity of surface bound heparinoid $P$}

Heparinised surfaces do not adsorb fibrinogen. Due to the similarity with the heparinoid $P$ coated surfaces we may assume the absence of fibrinogen adsorption on these surfaces. This would explain the virtual absence of platelet adhesion here. The coatings show a hydrogel like structure with a relatively high water content and as such they may be nonthromboadherent. The absence of coagulation can be connected with the anticoagulant activity of the heparinoid with the result that activation of antithrombin III takes place, followed by neutralisation of thrombin and other activated coagulation factors. In order to test this the uptake of AT-III by polyelectrolyte $\mathrm{P}$ coated surfaces was determined. ${ }^{10}$ TDMAC treated PVC powders were treated with solutions of heparinoid to obtain coatings of which the composition was derived from the adsorption isotherm. The coated powders were shaken with plasma for one hour and the plasma was filtered to determine in the filtrate the AT-III concentration. Then the treated powders were washed and shaken with a thrombin solution $(5 \mathrm{U} / \mathrm{ml})$. AT--III was determined and expressed in thombin neutralised units. The results of the AT-III adsorption determinations and the thrombin neutralization are given in Fig. 7. The AT-III adsorption is proportional to the surface concentration of the polyelectrolyte $\mathrm{P}$, as is the subsequent neutralisation of thrombin. Minimum levels of around $10 \mathrm{mg} / \mathrm{m}^{2}$ are required for nonthrombogenicity.

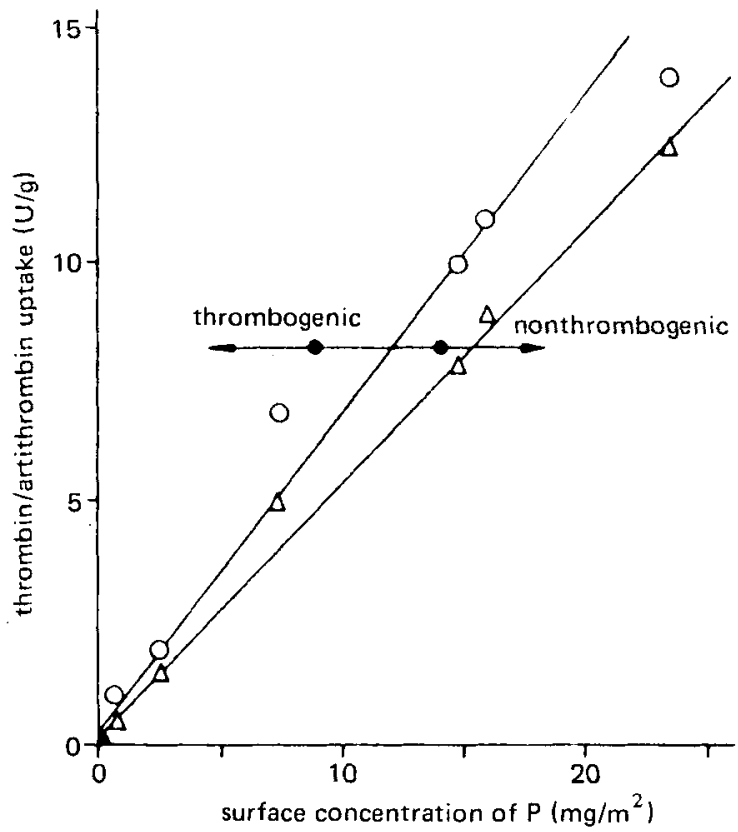

Iiig.7 Antithrombin adsorption $(O)$ and subsequent thrombin neutralization $(\triangle)$ by two step coatings of $P$ on TDMAC/PVC. 


\section{CONCLUSIONS AND FUTURE PERSPECTIVES}

A number of approaches have led to diverse blood compatible surfaces. What is lacking is a better fundamental insight in the processes involved in the interaction of the material and biological medium. A phenomenon such as the preferential adsorption of albumin on certain copolyether urethanes should be studied extensively, both from the materials as from the haematological and biochemical angles to obtain insight in the reasons for selective protein adsorption, which may offer the key to a final solution to the blood compatibility problem. The minimal interfacial free energy concept, which has led to non thromboadherent hydrogels, deserves further scrutiny, but need broader investigations in view of the recent discovery of higher platelet destruction with increasing gel water content. The field of polymeric heparinoids is, as a part of the field of polymeric drugs an open research area where advantages exist over routinely used anticoagulants such as heparin. The slow release of anticoagulan ts may offer improved opportunities for treatment. The effects of flow on blood compatibility are not extensively known, but research is carried out in many centres and also in the authors laboratory to evaluate the combined effects of shear and materials contact on blood compatibility.

\section{ACKNOWLEDGEMENT}

The members of the Biomaterials Group, Dr. T. Beugeling, Dr. L. van der Does and Dr. J. Feijen and Dr. P. E. Frochling of D.S.M. are greatfully acknowledged for their contributions, included in this paper. Finally the author thanks Mrs. T. Bergsma for the typing of the manuscript

\section{References}

1 Bruck, S. D., 'Blood compatible synthe tic polymers', 1973 Charles C. Thomas, Springfield, Illinois

2 Bruck, S. D., Biomat. Med. Dec. Artif. Organs, 1973, 1, 79

3 Bruck, S. D., J. Biomed. Mat. Re's. Symposium, 1977, 8, 1.

4 Brash, J. L. \& Lyman, D. J. in 'Chemistry of Biosurfaces,' 1971, Ch. 5, New York: Dekker.

5 Olsen, D. A. \& Kletschka, HI. D., 'Progress in Surface and Membrane Science', 1973, 331, New York: Academic Press.

6 Baier, R. E., Loeb, (i. I. \& Wallace (i. T., F'd. Proc., 1971, $30,1523$.

7 Oreskes, I. \& Singer, J. M., I. Inmun , 1961, 86, 338.

8 Lee, R. G. \& Kim, S. W., J. Biomed. Mator. Res., 1974, 8, 251.

9 Jloftman, A. S., J. Biomed. Mater. Res. Symposium, 1974, 5, 77.

10 Brash, J. L. \& Lyman, D. J., J. Biomed. Mater. Res., 1969, 3, 175.

11 Kin, S. W. \& Lee, R. G., 'Advances in Chemistry Series,' No. 145, 'A pplied Chemistry at Protein Interfaces', Washington D.C'. 1975.

12 Vroman, L., Progress Report PB 204601 NIAMD, National Technical Information Service, Sprinfield, Lllinois.

13 Lee, R. G. \& Kim, S. W., J. Biomed. Mater. Res., 1974, 8, 393.

14 Lyman, D. J., Klein, K. G., Brash, J. L., Fritzinger, B. K., Andrade, J. D. \& Bonomo, 1:. S., Thrombos. Diathes. Haw Suppl., 1970, 42, 109 .

15 Lyman, D. J., Knutson, K., McNeill, B. \& Shibatani, K. A., Trans. Am. Soc. Art. Organs., 1975, 21, 49.

16 Vroman, L. \& Adams, A. L., J. Biomed. Mater. Res., 1969, 3,43 .

17 Zucker, M. B. \& Vroman, L., Proc. Soc. Exp. Biol Med., $1969,131,318$

18 Vroman, L. \& Adams, A. L., J. Colloid Interf. Sci., 1966, 31, 188.

19 Horbett, T. A. \& Hoffman, A. S., Advances in Chemistry Series 145, 'Applied Chemistry at Protein Interfaces,' Washington D. C., 1975.

20 Lee, R. G. \& Kim, S. W., Thrombosis Res., 1974, 4, 485.
21 Van der Scheer, A., Ph. D. Thesis, Adsorption of Plasma Proteins, Twente University of Technology, Enschede, 1977.

22 Salzman, E. W., Fed. Proc., 1971, 30, 1503.

23 Falb, R. D., Pakahashi, M. T., Grode, G. A. \& Leininger, R. I., J. Bionted. Mater. Res., 1967, 1, 239.

24 Kim, S. W., Lee, R. G., Oster, H., Coleman, D., Andrade, J. D., Lent $z$, D. J. \& Olsen, D., Trans. Amer. Soc. Artif. Intern. Organs, 1974, 20, 449 .

25 Lee, R. G. \& Kim, S. W., J. Biomed. Mater. Res., 1974, 8, 393.

26 Jamieson, G. A., in 'Erythrocytes, thrombocytes, leucocytes, 1973, 209, Stuttgart: Theme Verlag.

27 Rembaum, A., Yen, S. P. S., Ingram, M., Newton, J. I. \& Hu, C. L., Biomat. Med. Dev. Art. Org., 1973, 1, 99.

28 Hemker, H. C. \& Kahn, M. J. P., Nature, 1967, 215, 1201.

28 a Feijen, J., 'Artificial Organs', (Ed. Kenedi, 1977, 235, London: McMillan Press Ltd.

29 Jorpes, J. E., 'Handbuch der Experimentellen Pharmakologie', Ed. Markwardt, l., 1971, 142, Berlin:

30 Ehrlich, J.\& Stivala, S., J. Pharm. Sci., 1973, 62, 517

31 Rosenberg, R. D. \& Daınus, P. S., J. Biol. Chem., 1973, 248, 6490 .

32 Porter, P., Porter, M. C. \& Shanberge, J. N., Clin. Chim Acta. $1968,19,411$.

33 Godal, II. C., Rygh, M., \& Laake, K., Thrombosis Res., 1974, $5,773$.

34 Yin, I:. T., Wessler, J. \& Stoll, R. J., J. Biol. Chem, 1972, 246, 3712 .

35 Dallus, P. S., llicks, M. \& Rosenbers, R. D., Nature, 1973, $246,355$.

36 Aronson, D. L., New Engl. J. Med., 1974, 290, 861

37 Buonassisi, V. \& Root, M., Biochim. Biophys. Acta, 1975, 385,1 .

38 Buonassisi, V., Exp. Cell. Res. 1973, 76, 363.

39 Murata, K., Nakilzawa, K. \& llamai, A., Atherosclerosis, 1975, 21, 93 .

40 Wort listes, J. \& Poluin, P. E., Thrombos. Diathes. Macmorh., $1974,33,26$.

41 Doane, W. M. \& Whistel, R. L., Arch. Biochem. Biophys. $1963,101,436$.

42 Wolfrom, M. L. \& Wang, P. Y., Carbohydr. Res., 1971, 18, 23.

43 Whistcl, R. L. \& Kosik, M., Arch. Biochem. Biophys., 1971 , $142,106$.

44 Inouc, Y. \& Nagasiwa, K., Carbohydr, Res, 1975, 37, 145

45 Laker, S. L. \& Stivala, S., Arch. Bioche'm. Biophys., 1966, 115,360 .

46 Citonclli, J. A., Carbohydr. Res., 1975, 37, 145

47 Feijen, J., Beugeling, T., Bantjes, A. \& Sinit Sibinga, C. Th. Biomaterials and interfacial phenomena, Cardiocirculatory analysis of aspects of diagnosis, assist, therapeutic and prosthetic devices Vol. IV, in the press, Karger, Basel, Switzerland

48 Lampert, H., Mïnchen Med. Wschr, 1930, 77, 586.

49 Lyman, D. J., Muir, W. M. \& Lee, I. J., Trans. Amer. Soc. Artif. Intern. Organs, 1965, 11, 301 .

50 Lyman, D. J., Klein, K. G., Brash, J. L. \& Jirizinger, B. K. Thrombos. Diathes. Haemorrh., 1970, 23, 120.

51 Andrade, J. D., Lee, H. B., Jhon, M. S., Kim, S. W. \& Hibbs, J. B., Trans. Amer. Soc. Artif. Intern. Organs, 1973, 19, 1.

52 Andrade, J. D., Med. Instrum., 1973, 7, 110.

53 Andrade, J. D., Dissert. Abstr, 1970, 30, 3614B.

54 Zisman, W. A., 'Advances in Chemistry Series', Washington, D.C., $196443,1$.

55 Baier, R. I: \& Bull, N. Y., Acad. Med., 1972, 48, 257.

56 Owens, D. K. \& Wendt, R. C., J. Appl. Pol, Sci., 1969, 13 1741 .

57 Srinivasan, S. \& Sawyer, P. N., J. Coll. Interf. Sci., 1970, 32, 456.

58 Srinivasan, S. \& Sawyer, P. N., J. Macromol. Sci., 1970, A4 3,51 .

59 Sawyer, P. N., Pate, J. W. \& Weldon, C. S., Am. J. Physiol, 1953, 175, 108

60 Murphy, P., Proc. Artif. Heart Conf., 1969, 99.

61 Mirkovich, V., Beck, R. li., Andrus, P. G. \& Leininger, R. I., J. Surg. Res., 1964, 4, 395.

62 Milligan, H. L., Davis, J. \& Edmak, K. W., J. Biomed. Mater. Res., 1968, 2, 51

63 Vogel, M. K., Cross, T. A., Bixler, H. J. \& Cuzman, R. J. Macromol. Sci., A4, $1970,3,675$.

64 Robertson, A. L., Cleveland Clin. Quart, 1965, 32, 99.

65 Volder, J. G. R., Krikham, R. L. \& Kilff, W. L., Trans. Am. Soc. Artif. Intern. Organs, 1973, 19, 38. 
Lyman, D. J, Brash, J. L. \& Klein, K. G., Proc. Artif. Heart Progr. Cont., 1969, 115, Washington, D.C., U.S. Printing Office.

67 Brash, J. L., Fritzinger, B. K. \& Bruck, S. D., J. Biomed. Mater. Res. 1973, 7, 313.

68 Nyilas, E. \& Ward, R. S., J. Biomed. Mater. Res. Symposium, $1977,1,69$

69 Lyman, D. J. Metcalf, L. C., Albo, D.Jr., Richards, K. I. \& Lamb, J., Trans. Am. Soc. Artif. Intem. Organs, 1974, 20B, 474

70 Picha, G., Gibbons, D. \& Auerbac-, R., Abstr. 3rd Ann. Meeting, Soc. Biomater., 1977, 25.

71 Brash, J. L., Fritzinger, B. K. \& Loo, B. H., PB 197352, National Techn. Inf. Service 1970.

72 Andrade, J. D. (cd.), Hydrogels for medical or related applications', ACS Symp. series No. 31, 1976.

73 Ratner, B. D., Hofttman, A. S., Hanson, S. R., Harker, L. A. \& Whitten, J. D., Abstr. 17th Macromol. microsymposiumMed. Polymers, Prague, 1977 to be publ. in J. Polym. Sci.

73a Vogel, M. K., Cross, R. A., Bixler, H. J. \& Guzman, R. J., in 'Biomedical Polymers', 1971, pp 181-198, New York: Marcel Dekker.

74 Lande, A. J., Trans. Am. Soc. Artif. Intern. Organs, 1970, 16,352 .

75 Imayi, Y., Takima, K. \& Nose, Y., ibid, 1971, 17, 6.

76 Kambic, H., Kiraly, R., Hillegas, D. \& Nose, Y., A bstr. 3rd Ann. Meeting Soc. Biomater. New Orleans, 1977, 42.

77 Leininger, R. 1., Cooper, C. W. Falb, R. D. \& Grode, G. A., Science, $1966,152,1625$.

78 Leininger, R. I., Epstcin, M. M., lalb, R. D., \& Grode, G. A., Trans. Am. Soc. Artif. Intem. Organs, 1966, 12, 151

79 Gott, V., Whiffen, J. D. \& Valiathan, S. M., Ann. N. Y. Acad Sci., $1968,146,21$.

80 Gott, V., Bull. N. Y. Acad. Med., 1972, 48, 216

81 Leininger, R. I., Ialb, R. D. \& Grode, G. A., Ann. N. Y. Acad Sci. 1968146,11 .

82 Grode, G. A., I'alb, R. D. \& Crowley, J. P., J. Biomed. Mater Res. Simposium, 1972, 3, 77

83 Leininger, R. I., Crowley, J. P., laalb, R. D. \& Grode, G. A. Trans, Am. Soc: Artif. Interm. Organs, 1972, 18, 312

84 Rea, W. J., Whitley, D. \& Eberle, J. W., Trans. Am. Soc. Artif. Intern. Organs, 1972, 18, 316.

85 Lagereren, I1. \& liriksson, J. D., ibid, 1971, 17, 10.

86 Hutnagel, C. A., Ann. N.Y. Acad. Sci., 1968, 146, 262.

87 Salycr, J. D., J. Biomed. Mater. Res. Symposium, 1971, 1, 105
88 Chawla, A. S. \& Chang, T. M. S., Biomat. Med. Dev. Art Organs, $1974,2,157$

89 Halpern, B. D. \& Shibakawa, R., Adv. Chem. Series, 1968, $87,197$.

90 Grodé, G. A., Anderson, S. J., Grotta, H. M. \& Falb, R. D. Trans. A m. Soc. Artif. Intern. Organs, 1969, 15, 1

91 Stoner, G. L., Srinivasan, S. \& Gileadi, L., J. Phys. Chem. $1971,75,2107$

92 Tanzawa, H., Mori, Y., Harumiya, N., Hori, M., Oshima, N. \& Idezuki, Y., Trans. Am. Soc. Artif. Intem. Organs, 1973, 19,188

93 l'roehling, P. E., Thesis - Antithrombogenic surface coatings based on a synthe tic heparinoid polyelectrolyte, Twente University of Technology, Enschede, Netherlands, 1977.

94 Van der Does, L., Hofman, J. \& Van Utteren, T. F. C. J. Polym. Sci., 1973, 11, 169.

95 Graf. R., Ann., 1963, 661, 111

96 Graf, R., Angew. Chem., 1968, 80, 179

97 Beugeling, T., Van der Does, L., Rejda, B. V. \& Bantjes, A., in Biocompatibility of implant materials, 1976, 187, London Sector Publishing Co.

98 Beugeling, T., van der Does, L., Bantjes, A. \& Sederel, W. L. J. Biomed. Mat. Res, 1974, 8, 375.

99 Beugeling, T., 17 th Macromol. Microsymposium, Med. Polymers, Prague 1977, to be published in J. Pol. Sci.

100 Van der Does, L., Beugeling, T., Froehling, P. E. \& Bantjes, A., 17 th Macromol. Microsymposium, Med. Polymers, Prague 1977, to be published in J. Pol. Sci

101 Hesselink, F. T., J. Electroanal. Chem., 1972, 37, 317

102 Silberberg, A., Pure Appl. Chem., 1971, 26, 583

103 Greenwood, I. C., Ilunter, W. M. \& Glover, J. S., Biochem. J., $1963,89,114$

104 J'rochling, P. E.., Kolar, Z. \& Bantjes, A., J. Coll. Interf. Sci. $1977,62,35$.

105 Mason, R. G., Shermer, R. W., \& Rodman, N. F., Am. J Pathol., 1972, 69, 271.

106 Mason, R. G., Shermer, R. W. Zucker, W. H. \& Brinkhous, K. M., in 'Eyrthrocytes, Thrombocytes, Leukocytes', 1973 263, Stuttgart: Thieme Verlag.

107 Mason, R. G., Bull. N. Y. Acad. Sci., 1972, 48, 407.

108 Beugeling, T., Feijen, J., Tijhuis, A. H. J., Froehling, P. I.., de Jongh, M. A., Looze-van Iperen, M. \& Bantjes, A., Proc Eur. Soc. Artif. Organs, 1976, 3, 76-82.

109 Abildgard, U., Scand. J. Clinic. Lab., Invest., 1968, 21, 89 